Michael J. Kelly

\title{
Gundemar the Ghost, Isidore the Historian: Rethinking Visigothic History from the Whispers of its Literature
}

\section{Introduction}

In Phantoms of Remembrance, Patrick Geary states that "[t]hose who could control the past could direct the future."1 Echoing Walter Benjamin's dictum that the past has meaning according to the chain of significations into which it is put and RG Collingwood's encapsulation theory, Geary shows that medieval writers selected elements of the past, discarded others, and organized the material into cognitively mnemonic historiographies, using false plots of comprehensiveness to misdirect historical enquiry.

Embracing Geary's interpretative paradigm, this chapter illustrates how early medieval Iberian authors were attuned to the functions of history-writing and employed mnemonic techniques. The exemplar for this is the fascinating story of the reign of the Visigothic King Gundemar (r. AD 610 - 612), as created by Isidore, bishop of Seville (c. AD 600-636). The following reading reveals what the silences and the whispers of Gundemar across Isidore's texts suppress, suggests why they do so, and demonstrates the medieval historiographical legacy of Isidore's attempt to erase Gundemar from historical existence - and thus from all future relevance.

\section{Gundemar's Conciliar Activities}

A dithematic name, Gundemar means war. ${ }^{2}$ Tragically, Gundemar failed to live up to his name, had little impact on the Visigothic kingdom and its church, and had no memorable or any communication with the great clerics of his time, such as Isidore. This is the false narrative that Isidore invented. Why?

1 Patrick Geary, Phantoms of Remembrance: Memory and Oblivion at the End of the First Millennium, Princeton 1994, 6.

2 Gunth(j)o (battle) + 'maerja' (famous). Thank you to Wolfgang Haubrichs for his explanation of these linguistic associations. Isabel Velázquez further contends that "guma” or "goma” was Gothic for "man". The slates show that Gund- or Gum- was not uncommon among Goths of the late sixth century. In slate 128, from Salamanca, one 'Gumari-' is making supplication to Reccared (see Isabel Velázquez, Las Pizarras Visigodas: Entre en latín y su disgregación. La lengua hablada en Hispania, siglos VI-VIII, Real Academia Española 2005, 426-432).

Ә OpenAccess. (c) 2021 Michael J. Kelly, published by De Gruyter. (cc))BY-NC-ND This work is licensed under the Creative Commons Attribution-NonCommercial-NoDerivatives 4.0 International License. 
The answer has to do with Gundemar's council. ${ }^{3}$ A plenary council, it dealt in its content with ecclesiastical matters that directly addressed multiple provinces and which affected them all. ${ }^{4}$ Gundemar and twenty-six bishops, from every region and province of the kingdom, signed the decretal. ${ }^{5}$ Only two attested to being there - Isidore and Innocentius (bishop of Mérida [c. 600-610s]). The main function of the council was to pronounce a decretal concerning the bishoprics of Cartagena and Toledo. ${ }^{6}$

In addition to the decretal, there was a supplementary constitution pronounced by Gundemar the day after the council, containing the signatures of fifteen bishops from around Carthaginensis, or, Carpetania. This Carthaginian constitution was meant, from Gundemar's point of view, to buttress the council's actions as expressed in the decretal, which it did. However, it also provides a rare glimpse into the conflicts and incriminations of the early 610s, otherwise veiled in the historical record.

Following the constitution and its signatures are three short suggessiones on behalf of Emilanem, bishop of Mentesa in Carthaginensis. ${ }^{7}$ Such an ordering in the texts and use of the suggessiones in this way implies a familiarity with the Romano-Visigothic legal tradition. In the Breviary of Alaric II, the decretal was a written decision applied universally as law across a unified political unit. Gundemar's court saw the decretal as a royal writ. ${ }^{8}$

The decretal's purpose was twofold: first, the demotion of the bishopric of Cartagena from its status as metropolitan see of the province of Carthaginensis. This demotion would be so absolute that subsequently no bishop of Cartagena would ever sign a Spanish council, from 610 until the end of the kingdom in the 710s. The second function was to elevate the bishopric of Toledo to the vacated post of metropolitan see of Carthaginensis. Gundemar became the first Visigothic king to formally elevate Toledo to the metropolitan status of Carthaginensis.

3 The authoritative edition of the Iberian councils is La Colección Canónica Hispana, ed. by Gonzalo Martínez Díez and (from 1982 as co-editor) Félix Rodríguez, 6 vols, Madrid, Consejo Superior de Investigaciones Científicas 1966-2002, referred to hereafter simply as $\mathrm{CCH}$, with respective volume noted. For the records of the council of Gundemar see CCH 6, 205-213.

4 IV Toledo 3, CCH 5 (note 3), 184 defines a plenary council as dealing with matters relevant to the wider church, fidei causa...aut quaelibet alia ecclesiae conmunis. The restructuring of metropolitan statuses and the seat of the king seems to fit this definition.

5 CCH 6 (note 3), 201: ob hoc, quia una eademque provincia est, decernimus ut sicut Betica, Lusitania vel Tarraconensis provincia, vel reliquae ad regni nostri regimina pertinentes.

6 CCH 6 (note 3), 201.

7 CCH 6 (note 3), 212-214.

8 The decretal is opened as such, but in the signatures, Gundemar, in his propria manu, refers to the text as edicti, hence the reference to the decretal as the Edictum Gundemari. If Gundemar saw the decretal as an edict, this further suggests its intention as a royal proclamation, a lex in confirmatione (on the latter see Isabel Velázquez, Leges in Confirmatione Concilii: The Relationship between the Monarchy and the Church in Visigothic Hispania, Visigothic Symposia 1 (2017), 57-80). 
The promotion of Toledo and demotion of Cartagena aimed at challenging the Byzantine position in the latter. The message of victory expressed by the conciliar activity was an act of propaganda, part of an ongoing war of rhetoric between Visigothic and Byzantine officials. ${ }^{9}$ Gundemar opens the decretal with an appeal to the bishops in a manner somewhere between a legalist approach and the pathos of Sisebut's Vita Desiderii of a few years later. ${ }^{10}$ Referring to the reign of his predecessor Witteric (r. 603-610), Gundemar acknowledges that wrongdoing had been done in Toledo. ${ }^{11}$ However, Gundemar would restore order, piety and prestige to the city and its church. ${ }^{12}$ The Byzantines had done a poor job defending the integrity of Cartagena, which recently had been subject to the assassination of its bishop, Licinianus, and the deposition of its governor, Comentiolus. ${ }^{13}$ Gundemar defended the city's faith and property and restored its dignity, despite stripping it of its authority.

Gundemar built legitimacy for Toledo as primatial see by tying this power back to the Catholic foundations of the kingdom. At III Toledo (the Third Council of Toledo, 589), Gundemar claims, Toledo was elevated to metropolitanate of Carthaginensis. His council was ratifying this move and correcting the error of Eufemius, bishop of Toledo at that council, who had located the city in Carpetania, suggesting the city was not even in Carthaginensis, let alone the center of its spiritual life. ${ }^{14}$ Gundemar says that Eufemius, and so by implication King Reccared (r. 586-601), Leander (bishop of Seville, c. 579-600), Massona (bishop of Mérida, c. 573-600), and the senior Goths at the council misunderstood the location of Toledo. However, evoking the populist appeal to commonsense, Gundemar says that Carpetania and Toledo were "undoubtedly" (procul dubio) part of Carthaginensis: the matter was settled. ${ }^{15}$

9 Evident, for instance, in the Comentiolus inscription of 589 or 590, on which see Jamie Wood, Defending Byzantine Spain: Frontiers and Diplomacy, in: Early Medieval Europe 18 (2010), 292.

10 CCH 6 (note 3), 205.

11 CCH 6 (note 3), 205-206: (...) sed etiam aeternorum adipisci gloriam meritorum. Nonnullam enim in disciplinis ecclesiasticis contra canonum auctoritatem per moras precedentium temporum licentiam sibi de usurpatione praeteriti principes fecerunt, ita ut quidam episcoporum Carthaginensium provinciae non revereantur contra canonicae auctoritatis sententiam passim ac libere contra metropolitane ecclesiae potestatem per quasdam fratrias et conspirationes inexploratae vitae omnes episcopali officia provehi atque hanc ipsam praefatae ecclesiae dignitatem imperii nostri solio sublimatam contemnere, perturbantes ecclesiastici ordinis veritatem euisque sedis auctoritatem quam prisca canonum declarat sententia abutentes.

12 In the Oxomensis, Vigilianus and Aemeliensis manuscripts, CCH 6 (note 3), 20.

13 See Wood, Defending Byzantine Spain (note 9), 315.

14 III Toledo, CCH 5 (note 3), 140: Eufimius in Christi nomini ecclesiae catholicae Toletanae metropolitanus episcopus provinciae Carpetaniae.

15 CCH 6 (note 3), 206-207: Illud autem quod iam pridem in generalis synodo concilii Toletani a venerabili Eufemio episcopo manus subscriptione notatum est, Carpetaniae provinciae Toletanam esse sedem metropolis, nos eiusdem ignorantiae sententiam corrigimus, scientes procul dubio Carpetaniae regionem non esse provinciam sed partem Cartagensis provinciae, iuxta quod et antiqua rerum gestarum monumenta declarant. On Gundemar's argument that Toledo had always been the metropolitan 
Formally speaking, then, the decretal starts with an implied demotion, or negation, of Carpetania, suppressing what may have been a vibrant postcolonial phenomenon: the re-emergence of a pre-imperial provincial identity.

The constitution approves the demotion and promotion, respectively, of Cartagena and Toledo, and provides glimpses into otherwise unseen tensions. In the constitution, one sees, if not an outright condemnation of Gundemar's authority, then dissenting opinions by Carthaginian bishops. ${ }^{16}$ These bishops, almost all junior or marginal, state that they do not condone Gundemar's specific actions or the precedent of royal authority over ecclesiastical appointments and administration. They confirm that Toledo is a metropolitan see on the basis of prior canon law, by way of II Toledo in 527. They avoid explicitly stating that Toledo is the metropolitan see of Carthaginensis by confirming simply that it is a metropolitan see. ${ }^{17}$

The council was extremely effective, regardless of the possible extent of dissension, which also divided bishops in at least one city in Carthaginensis. ${ }^{18}$ Through the council, Gundemar pre-established a way to maintain the ecclesiastical unity of Carthaginensis a decade or so before Toledo's conquest of the city. After Gundemar's council there was no need for any subsequent Visigothic king or council to make this move, and no bishop of Toledo ever again signed Toledo as in Carpetania. Moreover, in affirming the ancient boundaries of Carthaginensis, Gundemar moved the Toledan monarchy closer to Roman tradition, providing it with the cultural capital it needed against the Byzantines. ${ }^{19}$ Cementing the move, the next bishop of Toledo, the vir illustris and dux Helladius (bishop from 614 to his death in 633), was, prior to his conditioning at the monastery of Agali, the governor of Carthaginensis.

The conciliar activities of Gundemar demonstrate the presence of keen jurists and other legal officials in Gundemar's court and their appropriate education in, awareness of, and versatility for adapting imperial and Visigothic law. Evident too are legalist conciliar innovations previously attributed to Isidore's II Seville in 619, as well as explicit imitation of Byzantine practice for the purpose of affiliating Gundemar with the Byzantine emperor. ${ }^{20}$ Gundemar approaches this task from multiple angles, for example, signing the decretal as Flavius Gundemarus rex. This action in-

see of Carthaginensis, see also Jose Orlandis and Domingo Ramon-Lissón, Historia de los concilios de España romana y visigoda, Pamplona 1986, 246-260.

16 Such expressed dissension is nearly unprecedented in conciliar legislation. However, it appears also in III Seville, another council presided over by Isidore and suppressed from the Hispana.

17 CCH 6 (note 3), 210: fatentes huius sacrosanctae Toledo ecclesiae sedem metropolitani nominis habere auctoritatem.

18 Venerius and Teudorus both signed as bishops of the Carthaginian bishopric of Castolonensis: the former the decretal, the latter the constitution.

19 Meritxell Pérez Martínez, Tarraco en la Antigüedad tardía. Cristianización y organización eclesiática (III a VIII siglos), Tarragona 2012, 363-365.

20 Rachel Stocking, Bishops, Councils and Consensus in the Visigothic Kingdom, Michigan 2000, 129-130 (henceforth BCC). 
dicates that the council was an "ornate event" intended to imitate Byzantine-style authority in the presence of the collected Spanish bishops. ${ }^{21}$

\section{Isidore's Reactions}

Isidore's first appearance in the historical record is with his signature of the decretal of Gundemar, marking the two men as born into history together, at the same place, at the same time, for the same reason: elevating the authority of Toledo and its monarch. This was not the historical memory that Isidore wanted to be transmitted. Gundemar's council was a traumatic moment for Isidore in which he authorized the unilateral authority of the monarch over ecclesiastical affairs. The effects of the institutionalization of such prerogative quickly became manifest. The next king, Sisebut (r. 612-621), inaugurated his reign by appointing bishops and then reprimanding and replacing others. ${ }^{22}$ Isidore's Sententiae, Chronicles, De Origine Gothorum, and Hispana exclude Gundemar's council. Together they helped forge a powerful historiographical tradition that almost erased the council and Gundemar himself from the past.

\section{Sententiae}

The recognition of the powers that he had afforded to the monarch and their subsequent employment drove Isidore to develop his model of kingship ${ }^{23}$ in the Sententiae. ${ }^{24}$ In them, he attempts to reclaim authority for ecclesiastics. He promotes the monarchy for its salvific potential and claims that royal power is effective only when subordinate. ${ }^{25}$ Kings are a punishment from God; their appointment to lead

\footnotetext{
21 Visigothic kings signed a text as Flavius when it served rhetorical ("Byzantinizing") purposes in front of Hispanian audiences. For example, Reccared signed III Toledo and a decretum as Flavius, but signed personal letters as Rex. See Gregorius I, Registri L. VIII-XIV, ed. by Ludovic M. Hartmann, in: MGH Epp. II, Berlin 1890, IX, 227, 220 -221.

22 Epistulae Wisigothicae 7 and 3, ed. by Wilhelm Gundlach, in: MGH Epp. 3, Berlin 1892, 668-669 and 663-664; and, Jacques Fontaine, King Sisebut's Vita Desiderii and the Political Function of Visigothic Hagiography, in: Visigothic Spain, ed. by Edward James, Oxford 1980, 126, n. 1.

23 See Marc Reydellet, La Conception du Souverain, in: Isidoriana, ed. by Manuel C. Díaz y Díaz, León 1960, 457.

24 See Isidore of Seville, Sententiae 3.47-3.51, ed. by Pierre Cazier, in: Corpus Christianorum, Series Latina 111, Turnhout 1998. On the dating of Isidore's Sententiae to between 612 and 615 see Jose Carlos Martín, Une nouvelle édition critique de la Vita Desiderii de Sisebut, accompagnée de quelques réflexions concernant la date des Sententiae et du De uiris illustribus d'Isidore de Séville, Hagiographica 7 (2000), 141-145.
}

25 Isidore, Sent. 3.51 .3 (note 24): sub religionis disciplina saeculi potestates subjectae sunt. 
is based on humanity's original sin and the evil that unleashed. ${ }^{26}$ Kingship is an office, a duty to be fulfilled. ${ }^{27} \mathrm{~A}$ king's role is to mediate between men. He should be a rex and should rule as a leader of the people, equal in the eyes of God. ${ }^{28} \mathrm{~A}$ king is the servant of the people, not an intermediary between God and them, and certainly not between God and the bishops. ${ }^{29}$ He is to care for the Christian regnum, not show vice against or dictatorship over it. ${ }^{30}$ In the Sententiae, Isidore created a relationship between the crown and the church that was a partnership of semi-autonomous equals, which he had hoped would persuade Sisebut to embrace a constitutionally limited royal authority. ${ }^{31}$

\section{Chronicles}

In his Chronicles, Isidore completely ignores Gundemar, refusing to inscribe him or his council into the annals of significant persons and events. World history was to be without Gundemar. Isidore produced two versions of his Chronicles. The shorter was made around 627 for inclusion into the Origines (Etymologies). The longer was completed in 615 or 616 and then revised in $626 .^{32}$ Neither include any reference to Gundemar.

\section{De Origine Gothorum}

Complementing the historiographical-spiritual work of the Chronicles are Isidore's two redactions of the De Origine Gothorum. In them, Isidore references Gundemar by saying, essentially, “Gundemar was king after Witteric. He once tore up some Basque lands, another time attacked Roman soldiers, and later died by some regular ailment in Toledo".33

26 Isidore, Sent. 3.51.6, and 3.47.1 (note 24): Propter peccatum primi hominis humano generi poena divinitus illata est servitutis...Inde et in gentibus principes, regesque electi sunt, ut terrore suo populos a malo coercerent, atque ad recte vivendum legibus subderent.

27 See Reydellet, La Conception du Souverain (note 23), 458.

28 Isidore, Sent. 3.48-49 (note 24).

29 Isidore, Sent. 3.49 (note 24): dedit Deus principibus praesultatum pro regimine populorum (...).

30 Isidore, Sent., 3.48 .2 (note 24).

31 The concept, later expressed in IV Toledo 75, CCH 5 (note 3), 248-260, may have been derived from Flavius Corippus's In laudem Iustini August minoris Libri IV (see Flavius Cresconius Corippus, In laudem Iustini Augusti minoris Libri IV, ed. by Averil Cameron, London 1976.)

32 It could also have been revised in the years 631 and 654. For the authoritative edition and further discussion see Isidori Hispalensis Chronica, ed. by José Carlos Martín, Corpus Christianorum, Series Latina 112, Turnhout 2003.

33 Isidore, Chronica 59 (note 32). 
Since the conciliar activities of Gundemar were, it would seem, only introduced into historical memory in the 680s, the foundational historical record we have of him is this earlier Isidorian account. In it, Isidore avoids associating Gundemar with ecclesiastical affairs, or anything other than military endeavors. Sadly, Gundemar does not accomplish much by battle and does not die gloriously. In censoring Gundemar's actions, Isidore eliminated the origin story of Toledo's becoming metropolitanate and so denied historical significance to Gundemar and agency to Toledo's spiritual primacy.

This historiographical misdirection is evident throughout the text, for example, in the next chapter about Sisebut. ${ }^{34}$ Here, Isidore relates the opening of Sisebut's reign with his attempt at bringing people into communion with the church, as opposed to his autocratic control over ecclesiastical affairs. The reader gets no impression from the Gundemar and Sisebut chapters that ecclesiastical authority had been institutionalized in the monarchy, in Toledo, during this decade: Gundemar's depiction is lackluster and Sisebut is painted as zealous but ignorant. Isidore adroitly criticizes these figures without having to preserve the reasons behind the criticism, instead using the representations as pedagogical devices.

The De Origine Gothorum was a central component of Isidore's three origins-story narratives to shape a specific spiritual-historical trajectory: by them, memory is invented and directed to encourage future activity. Each of the origins texts - De Origine Officiorum, Origines, and De Origine Gothorum - was initially developed between the years 614 and 619. As a set, they relate the origins of the offices of the church and the duties of a cleric, the origins of language and knowledge, and the origins of the land and people, thereby consolidating into a pedagogical framework the ideal relationship of church, people, nation, and king.

\section{Hispana}

The most glaring exclusion of Gundemar's conciliar activities is from the canonical record constructed by Isidore and his Sevillan network and known as the Hispana. Three versions were produced between 633 and 694. They are known respectively as the Isidoriana, the Juliana, and the Vulgata. The Isidoriana is the earliest form, written between 633 and 636. ${ }^{35}$

\footnotetext{
34 Isidore, Chronica 60 (note 32).

35 On the dates of the construction of the Hispana see CCH 1 (note 3), 306-354 and CCH 6 (note 3), 9; Gonzalo Martínez Díez, Concilios españoles anteriores a Trento, in: Repertorio de Historia de las Ciencias Eclesiasticas en España, vol. 5, Siglos I-XVI, Salamanca 1976, 306-307; Felix Rodríguez, Los antiguos concilios españoles y la edición crítica de la colección canónica Hispana, in: Monumenta Iuris Canonici 6, ed. by Stephen Kuttner and Kenneth Pennington, Biblioteca Apostolica Vaticana 1980, 3-13. On the manuscript tradition, see the Introduction to CCH 1 and Chapter 2 of CCH 6.
} 
Excluded from the Isidoriana are Gundemar's conciliar activities, as well as other councils, including ones led by Isidore. In fact, the majority of councils from across the kingdom, held between 589 and 624, were excluded from the memory of ecclesiastical activities. ${ }^{36}$ The only councils from this period, between the conversion of the kingdom to Catholicism at III Toledo to the Isidore-led IV Toledo (633), to be included are two of the councils at Seville, held respectively in 590 and in 619. III Seville, led by Isidore in 624, was excluded from the official canonical records. The image it provides is that of a direct line of orthodox spiritual authority running from Isidore's brother and episcopal predecessor Leander at III Toledo through the memorable councils of Seville to IV Toledo when Seville symbolically conquers Toledo. That two councils signed and led by Isidore would have compromised this pedagogical narrative suggests that both must have had effects that Isidore wanted forgotten.

The chaos of the earlier 630s, with active rebellions and royal and episcopal usurpations, may have been seen by Isidore as an opportunity to achieve his aim of overturning the practical legacy of Gundemar's council. The Hispana - in the form of the Isidoriana - provided a perfect platform for this, especially since bishops had, as Isidore argues in the De Origine Officiorum, a special duty (speciale officium) to read the Scripture and the canons and from that knowledge to go forth and teach, to historicize in the way Isidore wanted. ${ }^{37}$

Isidore had other reasons too for misdirecting the historical memory of Gundemar. The council record shows a general lack of collegiality, with competing junior and senior bishops, ${ }^{38}$ and the explicit dominance of Seville and Mérida. This competition contradicted Isidore's vision of the bishop as at peace with his brothers and provided a reason not to have bishops learning and teaching it into the future. ${ }^{39}$ Also, Cartagena was intimately associated with Isidore's family: it was his hometown, his brothers Leander and Fulgentius frequented it, ${ }^{40}$ papal communication arrived to Seville through it, and its bishop (Licinianus) was a family friend. ${ }^{41}$ That it was Cartagena that was demoted, let alone in favor of Toledo, must have complicated matters and influenced Isidore's decision to erase Gundemar's council from the past.

36 The list includes the councils of Narbonne (589), II Saragossa (592), Huesca (598), Toledo (of 597), II Barcelona (599) and Egara (614). On the exclusions, see Stocking, BCC (note 20), 16, n. 57. For other excerpts of the Hispana and transmission of individual councils see Index Scriptorum Latinorum Medii Aevi Hispanorum, ed. by Manuel C. Díaz y Díaz and CCH 6 (note 3), 41.

37 Isidore of Seville, De ecclesiasticis officiis (de origine officiorum) 2.5, 1s. 67-72 \& 171-175, ed. by C. M. Lawson, in: Corpus Christianorum, Series Latina 113, Turnhout 1989.

38 Venerius and Teudorus: the former signed the decretal, the latter the constitution.

39 Isidore, Sent. 3.32.2 (note 24).

40 In the late 570s (Leander, Regula 23, ed. by Jaime Velázquez Arenas, Leandro de Sevilla: De la instrucción de las virgines y desprecio del mundo, Madrid 1979).

41 Isidore of Seville, De Viris Illustribus 29, ed. by Carmen Codoñer Merino, El "De Viris Illustribus" de Isidoro de Sevilla: Estudio y Edición crítica. Salamanca 1964. See also Licinius, Epistula 1, ed. by Jose Madoz, in: Liciniano de Cartagena y sus cartas. Edición crítica y estudio historicó, Madrid 1948, 84, 92-93. 
Isidore never wrote about Gundemar's council, an astonishing silence that suggests a serious concern about proliferating its memory and future functionality. Isidore was not simply omitting Gundemar from the canonical records, he was - intent on breaking the historical cycle of Gundemar - damning his memory. Gundemar was the ghost haunting Isidore the historian.

\section{Other Visigothic Reactions}

\section{Braulio}

Braulio (bishop of Zaragoza, 631-651), maintained Isidore's silence about Gundemar. In his De Viris Illustribus chapter on Isidore, Braulio excluded Gundemar from the list of kings under which Isidore lived, even though Braulio was Isidore's student in Seville during Gundemar's reign, or near to it. Braulio, a close ally of Isidore's and successor to his 'school' was faithful to the narrative that Isidore constructed, potentially with Braulio's assistance (the Hispana). ${ }^{42}$

\section{Ildefonsus}

In contrast to Braulio, Ildefonsus (bishop of Toledo, 657-667) wrote his own version of the DVI and in it re-introduced Gundemar to the list of kings associated with Isidore. ${ }^{43}$ Ildefonsus was no friend of Isidore's legacy. With his version of the DVI, Ildefonsus challenged the spiritual significance of Seville and the authority of Isidore's texts, such as the DVI, saying that Isidore continued the grand tradition of Jerome and Gennadius, as best he could. Unfortunately, he was not quite up to the task and so Ildefonsus had to rewrite the narrative. ${ }^{44}$

42 On the "school" of Isidore-Seville see Michael J. Kelly, Isidore of Seville and the "Liber Iudiciorum”: The Struggle for the Past in the Visigothic Kingdom, The Medieval and Early Modern Iberian World 80, Boston and Leiden, 2021.

43 Ildefonsus of Toledo, De viris illustribus 9, ed. by Carmen Codoñer Merino, in: Corpus Christianorum, Series Latina 114 A, Turnhout 2007.

44 Ildefonsus, De viris illustribus, preface (note 43). For discussion see Michael J. Kelly, The Politics of History-Writing: Problematizing the Historiographical Origins of Isidore of Seville in Early Medieval Hispania, in: Isidore of Seville and His Reception in the Early Middle Ages, ed. by Andrew Fear and Jamie Wood, Amsterdam 2016, 93-110. 


\section{Julian \& Ervig}

Julian (bishop of Toledo, 680 -690) and King Ervig (r. 680 -687) reintroduced Gundemar's conciliar activities into the canonical record at XII Toledo (681). This was a clear affront to the damnatio memoriae constructed by Isidore, especially as the purpose was to re-assert royal prerogative on the one hand and absolute authority of the Toledan church over the entire kingdom on the other. ${ }^{45}$ Julian, in the first alternative version of the Hispana - the so-called Juliana - placed Gundemar's council not back into chronological order, but rather out of place, making it especially meaningful in the present. The symbolic re-arrangement placed Gundemar's council into an alternative chain of signification.

\section{Extra-Iberian and Post-Visigothic Representations}

\section{Fredegar}

In his mid-seventh-century Chronicles, Fredegar says that "Witteric died this year, and was succeeded as king of Spain by Sisebut.” This reproduces the silence on Gundemar found in Isidore's Chronicles. It is possible that Isidore was so successful in his erasure of Gundemar that Fredegar, writing only a generation after Isidore's death and only two after Gundemar's, yet outside of the kingdom and away from its political intrigues, never heard of Gundemar.

\section{Chronicle of 741}

The Chronicle of 741 was written in the Iberian Peninsula, although it is mainly concerned with the East. The narration of Iberian history begins with Reccared. The author relies on Isidore's Gothic history - which was copied into the exemplar of the four extant chronicle manuscripts - saying of Gundemar that he reigned for a bit after Witteric. ${ }^{46}$

45 The use of damnatio memoriae was popular in late-/post-Roman legal codification and can be found throughout Justinian's Corpus Iuris Civilis (Codex 1.3.23; Dig. 28.3.6.11; Inst. 3.1.5). The Roman phrase was memoria damnata (but see also Codex 1.5.4.4; 7.2.2 and 9.8.6; Dig. 28.3.6.11 and 31.76.9; Inst. 3.1.5 and 4.18.3). The term damnatio memoriae has been in use since Christoph Schreiter's Iuridicam de Damnatione Memoriae, Praescitu Superiorum (Leipzig: Ph.D thesis, 1689).

46 On the Chronicle of 741 see Ann Christys, Christians in Al-Andalus: 711-1000, NY 2002: Chapter 3 and Ksenia Bonch Reeves, Visions of Unity After the Visigoths: Early Iberian Latin Chronicles and the Mediterranean World, Turnout: Brepolis, 2016: Chapter 2. 


\section{Chronicle of 754}

The Chronicle of 754 was written in Toledo or somewhere in the southeast several decades after Arab-Berber armies had overthrown the Visigothic kingdom. The text is thus also removed from the competitive discourses of Isidore's Iberia; ${ }^{47}$ its purpose is to demonstrate the ecclesiastical unity of the Peninsula. The chronicler begins the story of the Visigoths in Iberia with Helladius, Isidore and Sisebut, suggesting a deliberate decision to begin the narrative safely away from the memory of Gundemar, especially since this chronicler relied on the same manuscript of the histories of Isidore as the chronicler of $741 .^{48}$ In chapter 18 , the chronicler suggests knowledge of the Isidorian version of the Hispana. The use of this may explain her or his exclusion of Gundemar.

\section{Chronica Albeldense}

The Chronicle of Albeldense represents a shift in historical theory that occurred within the ninth century, when the function of chronicles, histories and origins became blurred. The Chronicle of Albeldense builds not on Isidore's Chronicles, but rather sees itself in relation to and as a continuation of Isidore's De Origine Gothorum. For the most part, it reproduces the representation of Gundemar in that text. However, instead of initiating the chapter with reference to the Byzantine emperor on the throne at the time of Gundemar's ascension, Phocas (r. 602-610), it mentions Heraclius (r. 610-641), the emperor at the time of Gundemar's passing. ${ }^{49}$

\section{Chronica Naieransis ${ }^{50}$}

The three-book, twelfth-century (c. 1160) Chronicles of Najera simply replicates Isidore's De Origine Gothorum on matters of Gundemar. ${ }^{51}$

47 For extended discussion of the Chronicle of 754 see Christys, Christians in Al-Andalus (note 46), $28-51$.

48 See Rodrigo Furtado, Isidore's Histories in the Mozarabic Scholarship of the Eighth and the Early Ninth Centuries, in: Ways of Approaching Knowledge in Late Antiquity and Early Middle Ages: Schools and Scholarship, ed. by Paulo Farmhouse Alberto and David Paniagua, Nordhausen, 2012, $264-287$.

49 Crónica Albeldense, ed. by Juan Gil Fernández, José L. Moralejo and Juan Ignacio Ruiz de la Peña, Universidad Oviedo 1985, 169.

50 Written between 1173 and 1194 at the Benedictine monastery, Santa María la Real, in Nájera, Spain (see Chronica Hispana saeculi XII, Pars II: Chronica Naierensis, ed. by Juan A. Estévez Sola, in: Corpus Christianorum, Continuatio Mediaevalis 71 A, Turnhout 1995).

51 Chronica Naierensis, 1.191, 1. 1 (note 50). 


\section{Lucas de Tuy}

Lucas de Tuy, writing his World Chronicle in thirteenth-century Leon, refers to Gundemar by copying Isidore's De Origine Gothorum chapter. ${ }^{52}$

\section{Rodrigo Jiménez de Rada}

In his Historia Gothicae, Rodrigo Jiménez de Rada also repeats the Isidorian legacy of Gundemar by citing Isidore's De Origine Gothorum. ${ }^{53}$

\section{Historia Silense}

The author of the early-twelfth-century Historia Silense - intended to glorify Alfonso VI (r. 1065-1109) - was explicitly aware of Isidore's writings, but does not mention Gundemar. $^{54}$

\section{Oxomense Manuscript Tradition}

The Oxomense manuscript tradition represents an alternative and a break in the Isidorian historiography of Gundemar. The oldest extant Spanish manuscript of the Hispana is the Codex Oxomense, ${ }^{55}$ the lost Ur-model for which a manuscript is made in Cordoba around the year $775 .^{56}$ The Codex Oxomense contains a Juliana redaction of the Hispana ${ }^{57}$ and is the archetype of the codices Vigilanus and Aemelianensis. ${ }^{58}$ These represent a single, Toledan-centered manuscript tradition surviving from about 775 to the 990 s and are the only to preserve Gundemar's council. Between the creation of the Codex Aemelianensis in 994 and the mid-thirteenth-century edi-

52 Lucas de Tuy, Chronica Mundi, 2.78.1-3, ed. by Emma Falque Rey, in: Corpus Christianorum, Continuatio Mediaevalis 74, Turnhout 2003.

53 Rodrigo Ximenez de Rada, Historia de rebus historiae, sive, Historia Gothica, 2.16.16-18, ed. by Centre Traditio Litterarum Occidentalium, Turnhout 2010.

54 MS Madrid BN 1181.

55 MS Escorial E.I.12.

56 On the relations to a lost 775 manuscript and the Cordoban origins of it in MS Escorial E.I.12 see Manuel C. Díaz y Díaz, Pequeñas aportaciones para el estudio de la 'Hispana', in: Revista Española de Derecho Canónica 17 (1962), 382-383.

57 CCH 6 (note 3), 109.

58 The Codex Vigilanus was produced between 974 and 976 and the Codex Aemelianensis between 992 and 994, see CCH 1 (note 3), 109-132 and CCH 1, 30-33, 111-119. 
tion of this Hispana tradition, another version of Gundemar's acts existed, ${ }^{59}$ although the medieval bishops of Toledo were unaware of it. ${ }^{60}$

\section{Chronica general de España}

The Chronica general de España commissioned by Alfonso X of Castile (r. 1252-1284) and written between the 1260s and 1280s repeats the information about Gundemar found in Isidore's De Origine Gothorum. However, it is the first medieval account to embellish the Isidorian details with contextualization of the situation outside of Spain during Gundemar's reign, indicating a potential awareness of the Oxomense tradition.

\section{Chronica general de España}

In 1563, Ambrosio de Morales sat down to continue Florian do Campo's 1553 Chronica General de España, which brought the history of Spain to 210 вс. Morales intended to extend the history's chronological scope, but he also wanted to expand the range of material covered. ${ }^{61}$ Morales did reintroduce dormant material, such as the history and significance of Carpetania, yet he maintained the general silence about Gundemar. In a reply to Morales, Miguel de Luna, in his Verdadera historia del Rey Don Rodrigo (1589) argues that the Goths deserved to lose their kingdom to the virtuous Arabic rulers. His story ignores Gundemar too.

\section{Conclusion}

The image of Gundemar as cunning, assertive, and successful in wresting authority over ecclesiastical affairs from clerical hands, and with the blessing of Isidore on top of that, has eluded historians medieval and modern. Isidore's Gundemar has lived a long historical life from the early Middle Ages to the modern world. In that time, he

59 CCH 6 (note 3), 44-48.

60 Its only traceable owners - the abbot of Oña, the Bishop of Oviedo, and the abbots of Sahagún, Silos, Cardeña and Carrión - were all located relatively close to one another in the northern Duero plateau.

61 Ambrosio de Morales, La cronicon de España; proseguiendo adelante de los cinco libros que el Maestro Florian de Ocampo dexo escritos, Alcalá de Henares, Juan Yñiguez de Lequerica, September 1574, prologue (unpaginated), 4. Ocampo had been appointed Cronista real in 1539. 
has gone from being a haunting figure to a shadowy footnote. ${ }^{62}$ The aim of this chapter has been to interrogate Isidore's history of Gundemar and its effects. This has revealed Isidore's turning Gundemar into a narrative ghost, demonstrated the reasons for and historiographical means by which Isidore manipulated memory to suppress the haunting figure, and, finally, indicated, in brief, the medieval legacy of that damnatio memoriae and its historical significance.

The historiographical tradition using Isidore and the Visigoths to legitimize centrality, Castilian superiority, Catholic hegemony and autocratic rule often repeats the broader Isidorian tradition, as it was invented from the early eighth century onward. This includes the damnatio memoriae of Gundemar. However, contrasting historical narratives - whether Miguel de Luna's to Ambrosio de Morales's, or, centuries later, Américo Castro's to Claudio Sanchez-Albornoz's - which struggle against/for the centrality of the Visigoths, against/for lineage and unity, also tend to repeat the damnatio memoriae of Gundemar. Perhaps actualizing this historiographical ghost can help facilitate a short-circuiting of problematic historiographical dialectics on Visigothic Iberia.

\section{Appendix: The Authenticity of Gundemar's Council}

The authenticity of the records of Gundemar's council has been a topic of discussion in Visigothic studies since the eighteenth century. The debate today is effectively settled, with a wide consensus of scholars supporting the authenticity of the material. Like historical objectivity, as it is commonly imagined, absolute knowledge about anything from the past (not even "the past" itself) is achievable. As such, there may still arise those who will reasonably challenge the authenticity of the Gundemar material. However, I believe that when we read that material critically against its historiography and the history that it is supposed to represent, the most defendable conclusion, with the evidence we have, is that Gundemar's council was a real event and the records we have pertaining to it are genuine, although edited, as other Iberian conciliar records. At present, I am compiling a comprehensive defense of the authenticity of the Gundemar material, but, because of the significance of the documents to the current chapter, I am including here a brief outline of select reasons to support the authenticity of the material.

There are only two potential points of forgery for the Gundemar conciliar material: the first is the court/ circle of Ervig and Julian of Toledo; the second is the compilers of the Escorial manuscripts, which preserve the records of the council. Neither of these sites are a convincing point of forgery. In the case of the former, several rea-

62 Jacques Fontaine, in his thousand-page classic Isidore de Séville et la Culture Classique dans l'Espagne Wisigothique, 2 vols, Paris 1959, mentions Gundemar once, on a single page, as a small part of a footnote. 
sons suggest that the Gundemar activities were, in fact, genuine. The earliest historical records we have of Gundemar's council are from the Juliana recension of the Hispana (remember, they were not included by Isidore in his version, for the reasons explained above). Since the first recording of the council is out of place, some scholars have questioned its authenticity. However, there are perfectly good reasons for the text having been revived and for that act not being a conspiratorial forgery.

It may always be unclear to historians what led to the deposition of Wamba and the election of Ervig - i.e. was it poisoning or a chance sickness that led to him entering a state of penitence, and was this a coup conspired by Julian and Ervig? What is certain is that Ervig and with him Julian felt the need to legitimize the new reign and specifically to reinforce the authority of Toledo. To do so, they made a number of important real and actual moves. For example, in XII Toledo, they eliminated "extraneous" dioceses, such as Elo, and the dioceses created by Wamba (XII Toledo 4). ${ }^{63}$ Canon 6 of XII Toledo re-asserts the primacy of the bishopric of Toledo and its right to appoint bishops in other provinces. The records of Gundemar's council would have been precisely the type of documentation needed to re-confirm such Toledan royal and ecclesiastical dominion over the kingdom, and so they were inserted into the Hispana.

That the records confirmed Toledo's agenda is cause to be initially skeptical, but the contextualization decreases that suspicion. Finding a document in the archives to defend one's thesis is convenient, surely, but not alone sufficient reason to doubt the text's authority. Moreover, in this case, there is ample evidence to demonstrate that this type of activity was not unusual amongst Visigothic writers and compilers and, excepting when Gundemar has been involved, it has not led historians down the path of forgery claims, suggesting that it is something about what we modern scholars building from the medieval historiography - believe of Gundemar that fuels the falsification myth.

The thinking behind the creation of the Hispana - like the Liber Iudiciorum was to advance a particular narrative, not to collect all previous records into annals or simply "functional" texts. Many conciliar texts were excluded from the Hispana and yet are known of by other means - e.g. independent records or discussion in the later councils (e.g. references to III Seville [625] in VI Toledo [638]) - that they did in fact occur. Other council records were re-arranged and reinserted into the canonical record when it was beneficial to do so, for example the council of Huesca (598) was formally recorded in 614 at the council of Egara.

Julian, following the literary-cultural customs of the time, decided to revive archival material that suited his aim. It is crucial to reiterate that the effects of Gundemar's council were felt in real time and can be traced throughout the seventh centu-

63 See Antonio Poveda Navarro, La creación de la sede de Elo en la expansión toledana de finales del s. VI en el S.E. Hispánico, in: Actas del XIV Centenario del III Concilio de Toledo (589-1989), Toledo 1991, 615-617. 
ry. If Ervig and Julian forged the Gundemar records, they would also have to have forged the historical record since the 610s, an unlikely scenario. What Ervig and Julian did, like their Visigothic contemporaries, was to manipulate the historical narrative in their favor, including and excluding material to fit their political aims. ${ }^{64}$ This was history-writing in seventh-century Hispania.

On the second potential point of forgery, Gundemar's conciliar records come to us via the Spanish manuscript tradition of the Hispana. They survive within a collection of documents known as the Appendix Toletana, which effectively preserve their "out-of-placeness". This being out of place has raised doubts about their authenticity, but again the concern seems to be more based on false associations of Gundemar. The Appendix Toletana is preserved in the tenth-century Escorial codices Vigilanus and Aemilianus, which are famous for containing unique materials not otherwise suspected of being forgeries. The Appendix contains seven Toledan documents, primarily from the decades surrounding Gundemar's council, including a letter between Count Froga and Bishop Aurasius of Toledo (Ep. Wis. 20) concerning issues referenced by Ildefonsus in his DVI 5. In addition to the independent verifications of non-Gundemar material, the marginalia of the Codex Aemilianensis (Escorial d.I.1) confirms the once independent and additional circulation of records of Gundemar's council - a not uncommon situation for council records. Written in the margins after the signatures of XII Toledo and just prior to the Incipit Decretum of Gundemar is a note by an uncertain hand which reads - Hoc decretum gundemari regis habetur in meo exemplari. ${ }^{65}$

From the data presented above, there seems to be insufficient evidence for the Gundemar documents being forgeries, whether of Ervig and Julian or the Escorial scribes. Furthermore, the authenticity thesis fits better with the activities of Gundemar, such as his notable diplomatic activity, construction of Toledan supremacy and involvement in church affairs, as seen in the letters of Bulgar (Ep. Wis. 14) and elsewhere. Ervig and Julian's resurrection of the Gundemar documents confirms that he was associated with such activity. ${ }^{66}$ That said, I would caution the reader that this short exposition has been meant only as a limited sketch of the fuller pro-authenticity argument - which, in my associated essay, will be buttressed by additional theses - by which to provide sufficient information to instill confidence in the authenticity of the material in question. ${ }^{67}$

64 In the codices Oxomense and Vigilianus, the records of I and II Seville are at the end, after the Appendix Toletana, which could indicate that Julian had also cut them from the record.

65 On the potential hand in the marginalia see Augustin Millares Carlo, Tratado Palaeografia Española, Madrid 1983, 51.

66 On this, see Stocking, BCC (note 20), 121, n. 13.

67 For more on the authenticity of Gundemar's council, see Jose Vives, Concilios Visigóticos e Hispano-Romanos, Barcelona 1963, 403-410; Gonzalo Martínez-Díez, Estudio, La Collección Canónica Hispana 1: Estudio, Madrid, Consejo Superior de Investigaciones Científicas, 1966, 209-220; Paul Séjourné, Le dernier père de l'Église. Saint Isidore de Séville, Paris 1936, 86-88; E. A. Thompson, The 
Goths in Spain, Oxford 1969, 159-160; Jose Orlandis and Domingo Ramos-Lissón, Historia de los concilios de España romana y visigoda, Pamplona 1986, 248-252; Isabel Velázquez Soriano and Gisela Ripoll López, Toletum, la construcción de una urbs regia, in: Sedes Regiae (ann. 400-800), ed. by Gisela Ripoll and José María Gurt, Barcelona 2000, 521-571; and, Meritxell Pérez Martínez, Tarraco en la Antigüedad tardía. Cristianización y organización eclesiática (III a VIII siglos), Tarragona 2012, 403. For arguments questioning the authenticity of the texts, see Giovanni Domenico Mansi (ed.), Conciliorum omnium maxima collectio, 10.511; Felix Dahn, Die Könige der Germanen 5, Leipzig 1885, 175; and Antonino González Blanco, El decreto de Gundemaro y la historia del siglo VII, Los Visigodos. Historia y civilización, Antiqüedad y Christianismo 2, Murcia 1985 and ibid., La historia del S.E. peninsula entre los siglos III-VIII d.C. (Fuentes literarias, problemas y sugerencias), Del Conventus Carthaginiensis a la Chora de Tudmir. Perspectivas de la historia de Murcia entre los siglos IIIVIII Antiqüedad y Christianismo 2, Murcia 1985, 71. 
